\title{
Clinical Evaluation of the Efficacy of Coronally Advanced Flap in Combination with Platelet-Rich Fibrin Membrane in the Treatment of Miller Class I Gingival Recessions
}

\author{
Omar Alabood $^{1 *}$, Mohammed Alasqah², Nawaf Alhomodi ${ }^{2}$, Noorah Alqahtani $^{1}$, Khalid Gufran $^{2}$, Sami Shafiq $^{3}$ \\ ${ }^{1}$ Periodontist and Implantologist, Riyadh Specialist Dental Center, Riyadh, Saudi Arabia; ${ }^{2}$ Associate Professor, Department of \\ Preventive Dental sciences, College of Dentistry, King Saud university, Riyadh, Saudi Arabia; ${ }^{3}$ Department of Periodontology \\ and Preventive Dentistry, Riyadh Elm University, Riyadh, Saudi Arabia
}

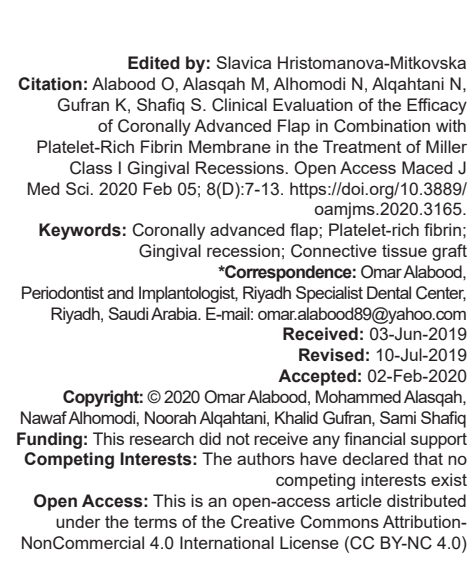

\begin{abstract}
BACKGROUND: Gingival recession has been associated with dentinal hypersensitivity, root caries, and esthetic compromise. Root coverage procedures aim at providing both tangible and intangible benefits to the patients Various procedures have been tried to obtain root coverage of single-rooted teeth. Miller Classes I and II gingival recessions hold out the best promise for root coverage as there is no interdental bone and soft-tissue loss associated with these recessions.

AIM: The objective of the study was to evaluate and compare the effectiveness of coronally advanced flap (CAF) with platelet-rich fibrin (PRF) membrane with CAF + connective tissue graft (CTG) on recession coverage.

MATERIALS AND METHODS: A total of 16 patients required recession coverage for a single tooth were divided into two groups. The test group received CAF + PRF while the control group got CAF + CTG. Different parameters were taken preoperatively (amount of recession, width, and thickness of attached gingiva) and repeated for the two groups 2 months after surgery.

RESULTS: Comparing the two groups after 2 months from surgery showed that the PRF not only has an effect in the management of recession but also has a greater effect on tissue thickness.

CONCLUSION: PRF is a minimum invasive approach and a promising material for root coverage and manipulating the gingival biotype.
\end{abstract}

\section{Introduction}

Apical displacement of the gingival margin beyond the cement-enamel junction (CEJ) is known as gingival recession. It can cause functional and esthetic problems, increasing the incidence of root caries, hyper sensitivity, and progressive attachment loss [1], [2], [3]. Bone dehiscence, gingival biotype, high frenal attachment, traumatic tooth brushing, and tooth malposition form the main factors of gingival recession [4], [5]. Complete root coverage resolving the recession problem and gaining a good homogenous appearance conceding the adjacent soft tissue with a minimal probing depth is the ultimate goal of the root coverage procedure [6]. The platelet-rich fibrin (PRF) was developed in France [7]. It has an advantage to the plateletrich plasma which was the first generation of platelet concentrate include the lack of biochemical modification as anticoagulant, ease of preparation, and minimal expense.

Hence, the study was conducted to clinically evaluate the efficacy of coronally advanced flap (CAF) in combination with PRF membrane or connective tissue graft (CTG) in the treatment of Miller Classes I and II gingival recessions and comparing CTG and PRF, if there are any differences between them on recession coverage and their effect on width and thickness of attached gingiva.

\section{Methodology}

A randomized clinical trial with 16 selected sites from patients enrolled in the postgraduate and undergraduate clinics at Riyadh Colleges of Dentistry and Pharmacy was conducted. Patients received a complete periodontal examination before the study, and patients fulfilling the study inclusion and exclusion criteria and who wish to participate in the study were included in the research.

The purpose of the study was explained to all patients, and consent forms were obtained. The study was approved by the Research Ethics Committee of Riyadh Elm University with registration number FPGRP/43631002/159.

\section{Inclusion criteria}

The following criteria were included in the study: 
1. Be at least 18 years of age

2. Display no evidence of acute periodontal infection (e.g., abscess)

3. Have at least six teeth in both maxilla and mandible

4. Miller Class I where the recession extended apically but did not reach the mucogingival line.

\section{Exclusion criteria}

The following criteria were excluded from the study:

1. Patients with any known acute/chronic systemic disease or on/need of medication which has a direct effect on periodontal tissue

2. History of severe psychological conditions or limited mental capacity

3. Pregnant or lactating mother

4. Patients undergoing or have undergone organ transplantation or cancer therapy

5. Patients with any oral mucosal inflammatory condition (aphthae, lichen planus, leukoplakia, or oral cancer).

After examination, subjects were divided into two groups randomly:

$\begin{array}{ll}\text { - } & \text { Group I - CTG + CAF } \\ \text { Group II - PRF + CAF }\end{array}$

\section{Surgical procedure}

\section{Group I - sub-epithelial CTG}

The procedure is basically a combination of a partial-thickness coronally positioned flap and a free CTG.

\section{Recipient site}

The root surface was scaled and root planned to flatten prominent convexities and to remove any softened root structure, endotoxins, and composite restorations. A no. 15 scalpels were used to outline the surgical site, making sure to raise a partial-thickness flap with no incisions made down to the bone. Two vertical incisions were made and extended adequately into the mucosal tissues to permit coronal positioning of the flap. Apically, the undersurface of the flap was released from the underlying periosteum through a horizontal incision, which will permit coronal positioning of the flap.

\section{Donor site}

CTG was harvested from the palate (preferably from the same side), a straight, horizontal incision was made approximately 5-6 $\mathrm{mm}$ from the free gingival margin. The length and width of the partial-thickness palatal flap varied with the size of the exposed root to be covered. It is continued apically to the same level as the first incision. This second incision produced a connective tissue wedge with a $2-3 \mathrm{~mm}$ wide epithelial border and was 1.5-2 $\mathrm{mm}$ in thickness. After harvesting the CTG, the palate was sutured with a combination of horizontal mattress sutures or continuous sling sutures.

\section{Graft placement}

The graft was trimmed to the required size and then placed so that the epithelial border is positioned above the CEJ and onto the enamel. This will ensure greater root coverage, predictability, and enhanced esthetics. Intimate graft-root contact will be achieved by first stabilizing the graft laterally with interrupted sutures and then using a continuous sling suture around the necks of the teeth for cervical positioning and stabilization. The primary flap will be coronally positioned and sutured to cover as much of the graft as possible (Figure 1).
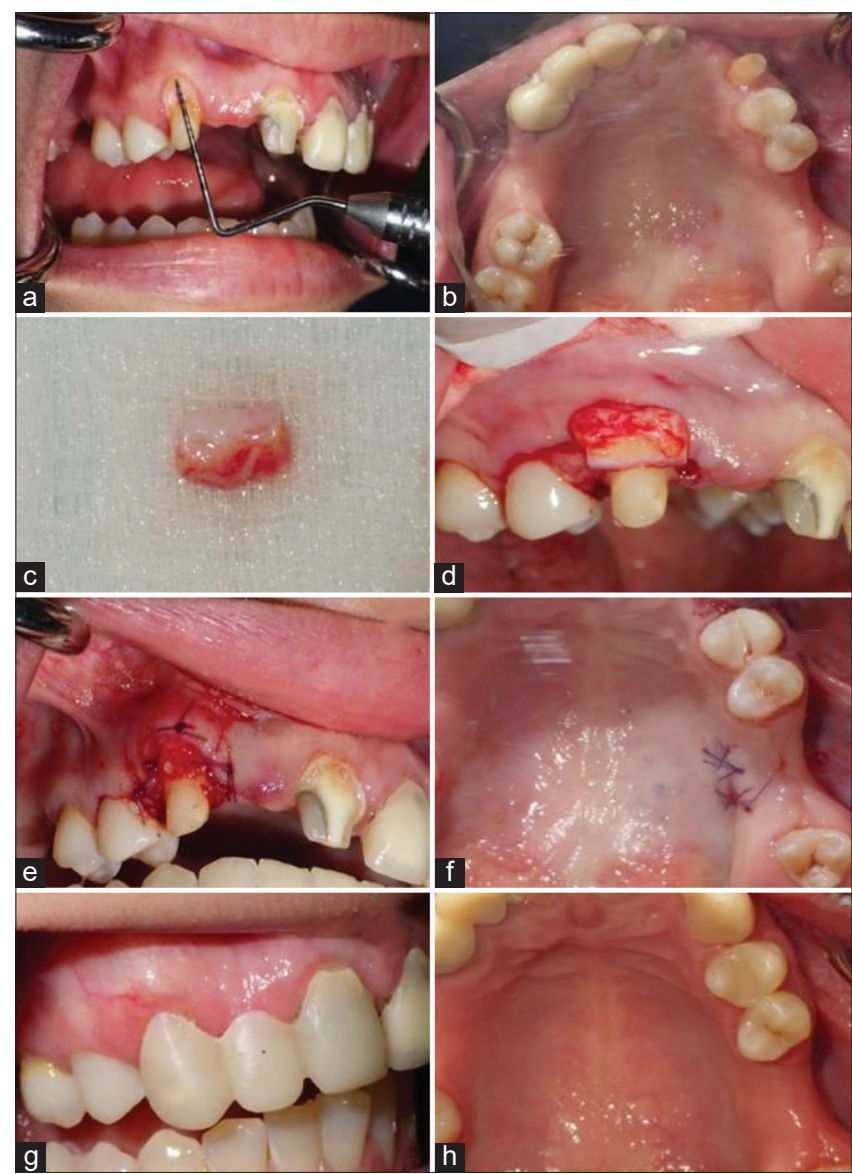

Figure 1: Pre-operative measurements of the recipient site. (a) Presurgical measurement of the donor site, (b) the harvested connective tissue graft (CTG) from the donor site, (c) placement of the CTG on the recipient site, (d) graft placement at the recipient site, (e) suturing and adapting the CTG with the flap, ( $f$ ) closure of the palatal wound by suture, $(g)$ the recipient site after 2 months, (h) the donor site after 2 months 


\section{Group II - PRF + CAF}

\section{PRF membrane preparation}

On the day of surgery, the required amount of blood was drained into a $10 \mathrm{ml}$ test tube and centrifuged immediately for $10 \mathrm{~min}$ at $3000 \mathrm{rpm}$ without the addition of anticoagulant. PRF membrane was squeezed out from the fluids in the fibrin clot immediately to prevent the initiation of clotting cascade due to the absence of anticoagulants agents.

\section{PRF placement}

The PRF membrane was trimmed to the required size and folded to increase its thickness then placed so that the coronal border is positioned above the CEJ and onto the enamel. Then, the primary flap was coronally positioned and sutured to ensure the coverage of the PRF membrane. The flap was positioned laterally with interrupted sutures and coronally with a suspensory sling suture (Figure 2).

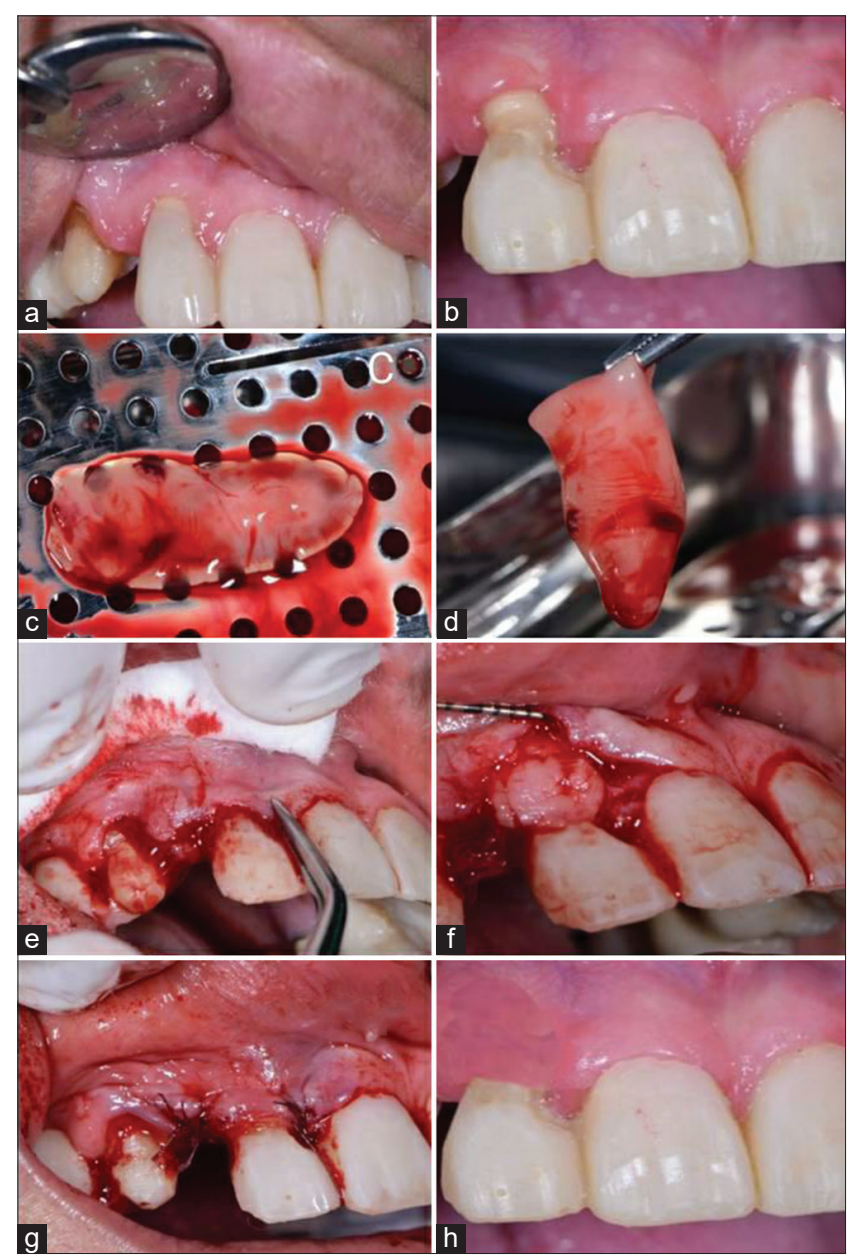

Figure 2: Pre-operative measurements of the recipient site. (a) Removal of composite from the root surface, (b) placing the plateletrich fibrin (PRF) membrane on the PRF plate and applying pressure, (c) folding the PRF membrane to make it thicker, (d) reflecting the recipient site for the PRF placement, (e) placing the folded PRF membrane on the recipient site, (f) stabilizing the membrane with suture and advancing the flap coronally, (g) follow-up after 2 months healing
Post-operative instructions were given for both the groups and asked to visit 2 weeks and 8 weeks after the surgery.

\section{Measurements}

The measurement taken pre-surgery and postsurgery were,

- $\quad$ Probing pocket depth on three surfaces mesiobuccal, mid-buccal, and distobuccal with University of North Carolina (UNC) probe

- $\quad$ Clinical attachment loss on three surfaces mesiobuccal, mid-buccal, and distobuccal with the use of UNC probe

- Thickness of the gingiva with the use of endodontic file and rubber stopper

The amount of attached gingiva is measured with the use of UNC probe

- The recession is measured on mesiobuccal, mid-buccal, and distobuccal with the use of UNC probe for each patient he will have a specific reference point, which is the highest tip of the crown.

Statistical analysis was done using $\mathrm{R}$ programming language for statistical computing. Shapiro-Wilks test was used to test the normality of the data, the result showed that the data were not normally distributed $(p<0.000)$, the median value of three sides (buccal, distal, and mesial) was used as single measurement for each patient on recession, width, and thickness of attached gingiva. Non-parametric statistical test was used for analysis. Wilcoxon signed-rank test was used to test the effect of surgery.

\section{Results}

Table 1 shows that there was a statistically highly significant difference in recession measurement (median) pre- and post-CTG surgery $(p=0.014)$ with $95 \%$ C.I $(0.84,1.66)$. The median value of the width of attached gingiva pre- and post-CTG surgery showed that there was no statistically significant difference ( $p=0.07$ ) whereas the median value of gingival thickness pre- and post-CTG surgery was statistically significant difference $(p=0.032)$.

Table 2 shows descriptive statistics by the median for the three measurements pre/post- CTG.

Table 1: Results of connective tissue graft

\begin{tabular}{|c|c|c|c|}
\hline Parameters & $\begin{array}{l}\text { Wilcoxon signed-rank test } \\
\mathrm{p}\end{array}$ & Results & $\begin{array}{l}\text { Cl for differences } \\
\text { (pre/post) }\end{array}$ \\
\hline Recession & $0.014^{\star}$ & $\begin{array}{l}\text { CTG has } \\
\text { significant effect }\end{array}$ & $\begin{array}{l}95 \% \mathrm{Cl} \\
(0.84,1.66)\end{array}$ \\
\hline $\begin{array}{l}\text { Width of attached } \\
\text { gingiva }\end{array}$ & 0.072 & $\begin{array}{l}\text { CTG has no } \\
\text { significant effect }\end{array}$ & Not valid \\
\hline $\begin{array}{l}\text { Gingival } \\
\text { thickness }\end{array}$ & $0.032^{*}$ & $\begin{array}{l}\text { CTG has } \\
\text { significant effect }\end{array}$ & $\begin{array}{l}\text { Only } 80 \% \mathrm{Cl} \\
(-1,-0.5)\end{array}$ \\
\hline
\end{tabular}


The result showed that there was decreasing in recession measurement post-CTG surgery from 1.33 to 0 and increasing in thickness measurement post-CTG surgery from $<0.5$ to 1.25 , while there was no change in measurement of the width of attached gingiva.

Table 2: Descriptive statistics (median of measures - CTG)

\begin{tabular}{lll}
\hline Parameters $(\mathrm{mm})$ & Median & \\
\cline { 2 - 3 } & Pre-CTG surgery & Post-CTG surgery \\
\hline Recession & 1.33 & 0 \\
Width of attached & 2 & 2 \\
Thickness & 0.5 & 1.25 \\
\hline CTG: Connective tissue graft. & &
\end{tabular}

Table 3 shows the results of PRF cases after Wilcoxon signed-rank test that there was a highly statistically significant difference in recession measurement, the width of attached gingival measurement and thickness measurement pre- and post-PRF surgery.

Table 3: Results of platelet-rich fibrin parameter

\begin{tabular}{|c|c|c|c|}
\hline Parameters & Wilcoxon signed-rank test & Results & $\begin{array}{l}\mathrm{Cl} \text { for differences } \\
\text { (pre/post) }\end{array}$ \\
\hline Recession & $0.010^{*}$ & $\begin{array}{l}\text { PRF has } \\
\text { significant effect }\end{array}$ & $\begin{array}{l}60 \% \mathrm{Cl} \\
(0.99,1)\end{array}$ \\
\hline $\begin{array}{l}\text { Width of } \\
\text { attached }\end{array}$ & $0.007^{*}$ & $\begin{array}{l}\text { PRF has } \\
\text { significant effect }\end{array}$ & $\begin{array}{l}95 \% \mathrm{Cl} \\
(-1.99,-0.06)\end{array}$ \\
\hline Thickness & $0.012^{*}$ & $\begin{array}{l}\text { PRF has } \\
\text { significant effect }\end{array}$ & $\begin{array}{l}90 \% \mathrm{Cl} \\
(-1.5,-1)\end{array}$ \\
\hline
\end{tabular}

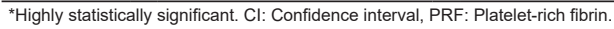

Table 4 and Figure 3 show descriptive statistics by median for the three measurements pre/post-PRF surgery.

Table 4: Descriptive statistics (median of measures of PRF) in $\mathrm{mm}$

\begin{tabular}{lll}
\hline Parameters & Median & \\
\cline { 2 - 3 } & Pre-PRF surgery & Post-PRF surgery \\
\hline Recession & 1.33 & 0.5 \\
Width of attached & 1.5 & 2.5 \\
Thickness & 0.5 & 2 \\
\hline
\end{tabular}

Result showed that there was decreasing in recession measurement post-PRF surgery from 1.33 to 0.5 and increasing in thickness measurement post-PRF surgery from $<0.5$ to $<2$ and increasing in measurement of width of attached post-PRF surgery from 1-1.5 to 2.5 .

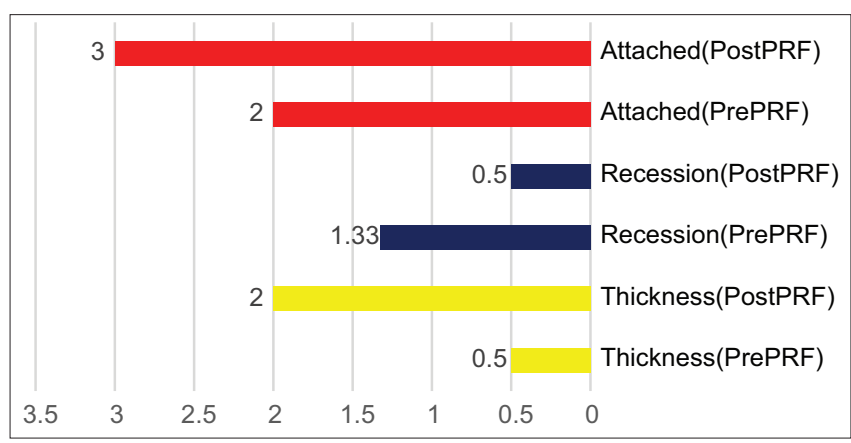

Figure 3: Pre/post platelet-rich fibrin - surgery median values in $\mathrm{mm}$

Table 5 shows after Mann-Whitney U-test that there were no significant differences in the measurements (recession, thickness, and width of attached gingiva) pre-CTG surgery and pre-PRF surgery.
Table 5: Result of comparing pre connective tissue graft and pre platelet-rich fibrin

\begin{tabular}{lll}
\hline Parameters $(\mathrm{mm})$ & Mann-Whitney U-test & \\
\cline { 2 - 3 } & Test value & $\mathrm{p}$ \\
\hline Recession & 24.5 & 0.44 (NS) \\
Thickness & 32 & 1 (NS) \\
Width of attached & 42 & 0.26 (NS) \\
\hline NS: No significant difference. & &
\end{tabular}

Whereas, Table 6 and Figure 4 show, there were highly statistically significant differences between postCTG and post-PRF surgery in recession measurement, in thickness measurement, but there were no significant differences in the width of attached gingiva like,

Table 6: Result of comparing between post-CTG and post-PRF

\begin{tabular}{|c|c|c|c|}
\hline Parameters $(\mathrm{mm})$ & Mean rank & Mann-Whitney test & Results \\
\hline \multicolumn{4}{|l|}{ Recession } \\
\hline CTG & 5.88 & \multirow[t]{2}{*}{0.023} & \multirow{2}{*}{$\begin{array}{l}\text { Significant difference } \\
\text { between CTG and PRF }\end{array}$} \\
\hline PRF & 11.3 & & \\
\hline \multicolumn{4}{|l|}{ Thickness } \\
\hline CTG & 5 & \multirow[t]{2}{*}{0.0007} & \multirow{2}{*}{$\begin{array}{l}\text { High significant } \\
\text { differences }\end{array}$} \\
\hline PRF & 12 & & \\
\hline \multicolumn{4}{|l|}{ Attached } \\
\hline CTG & 8 & \multirow[t]{2}{*}{0.67} & \multirow[t]{2}{*}{ No significant differences } \\
\hline PRF & 9 & & \\
\hline
\end{tabular}

1. The mean rank of recession after PRF (11.3) is higher than mean rank after CTG (5.88), which indicates that recession had higher values in patients having PRF surgery than CTG patients due to the greater coverage by CTG

2. The mean rank (12) of thickness after PRF is higher than the mean rank (5) after CTG, which indicates that thickness had a higher value in patients who had PRF surgery than CTG patients

3. The mean rank (9) of the width of the attached gingiva after PRF is higher than mean rank (8) after CTG, which indicates that attached gingiva had higher width in patients who had PRF surgery than CTG but not significant.

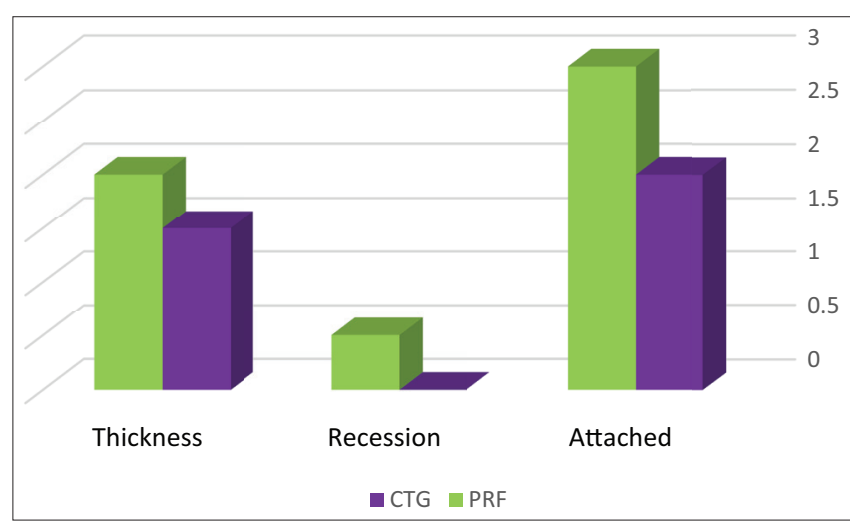

Figure 4: Comparing between connective tissue graft and plateletrich fibrin

\section{Discussion}

Gingival recession treatment is frequently managed by the use of autograft, which can be harvested either from the palate or the edentulous ridge. It is also important to know that sometimes patients may have either shallow palate or thin palatal 
tissue, so the idea of harvesting cannot be done [8]. Hence, several combination therapies for root coverage including platelet concentrated graft were suggested in a systematic review.

The use of CTG for root coverage was chosen for the present study as it was considered a gold standard, and the esthetic result was much better and well accepted by both the patient and the dentist [9]

The present study showed that increase of thickness with the CTG group was $<0.5-1.25 \mathrm{~mm}$, which was in accordance to Zucchelli et al. [10] as the same procedure for positioning of CTG was done, but it was in contrast to the original Langer and Langer [9]. Hence, the end result was good, but esthetically, it was not similar to Zucchelli et al. [10].

The present study showed that the recession measurement post-CTG surgery was reduced, increasing thickness but no significant change in measurement of the width of attached gingiva. Several studies have been done and monitored the efficacy of the CTG in the treatment of gingival recession with full coverage and followed it up to 4 years, and it was found that CTG has the rate of maintenance of its integrity [11]. In another study on the CTG, it was found that they can provide a good amount of keratinized gingiva [12].

The PRF group in the present study showed a decrease in recession measurement post-PRF surgery, but full coverage was not accomplished. There was a significant increase in thickness measurement post-surgery, which may be due to the folding of the PRF membrane and placing it on the site. There was increasing in the measurement of the width of attached gingiva post-PRF surgery, which may be due to less amount of attached gingiva preoperatively in most of the cases of the PRF group, so the increase was higher than the CTG group.

Several studies have been done on PRF for treating gingival recession and reported a similar result in recession coverage as compared to the present study [13], [14]. The present study showed reductions of clinical attachment level at 1 and 2 months postoperatively in both groups as compared to baseline. This gain was accomplished by the decrease in both the postpartum depression and the amount gained by recession coverage. This is in agreement with a histological study [15] which compared the use of CAF + CTG and CAF + PRF, and they found that epithelium thickness in the two groups was the same, but the rete-pegs length in the PRF group was much deeper than the CTG group at 6 months biopsies. They suggested that these newly developed rete-pegs that are in the keratinized layer of the epithelium my help in providing mechanical retention and resistance from any irritation [16]. Several growth factors including transforming growth factor-beta 1 (TGF- $\beta 1$ ), plateletderived growth factor-AB (PDGF-AB), and vascular endothelial growth factor (VEGF) will attract endothelial cells to perform angiogenesis and also help in recruiting epithelial, fibroblast, and endothelial cells for repair of tissues and wound healing with the help of the fibrin matrix that can act as an adhesive between the tissue and the root surface and with their help there will be an improvement in attachment of the cells and will help in prevention of shrinkage [17], [18].

An increase in the amount of the attached gingiva can be explained by the ability of the connective tissue to proliferate from the periodontal ligament. The underlying connective tissue can stimulate surface epithelium to keratinize, so it can be assumed that the newly formed connective tissue has the ability to induce keratinization of the overlying epithelium [19]. A case report [20] showed similar results, but with the difference in the thickness of the tissue, this was because, in the present study, the amount of PRF membrane obtained was manipulated by folding the PRF membrane to make it thick.

In a meta-analysis [7], the importance of gingival thickness for long-term stability and its importance in preventing the recurrence of the recession was noticed. The sutures were removed after 2 weeks to give sufficient time for healing and stabilization of the wound similar to the study conducted by Hiatt et al. [21]. A systematic review on the removal of sutures earlier than 10 days in both absorbable and non-absorbable suture showed it can affect the outcome of surgeries negatively and for a positive outcome removal of sutures should be done after 10 days or more [22]. As this period, it is crucial to give the $3^{\text {rd }}$ phase for granulation tissue maturation a proper adaptation and secure sutures for regeneration and repair [23]. The CTG maturation starts during this week and the normal vascular system has formed [24], [25]. On the other hand, during the $1^{\text {st }}$ week, the PRF releases slowly several growth factors, such as TGF $\beta 1$, PDGF-AB, and VEGF [26], [27]. Hence, proper stabilization is needed during this period.

\section{Conclusion}

The use of CAF in combination with PRF is a predictable procedure in the treatment of Miller Classes I and II gingival recession. PRF gave a faster healing and thicker tissue, which was maintained up to the 2 months follow-up. The increase in the thickness of keratinized gingiva is very important in preventing further recession and maintains gingival integrity for a long period of time. PRF might possess some regenerative factors and has the ability to increase the rate of healing. 


\section{Limitation}

Small sample size and inability to perform the procedure in split-mouthth design are the limitation of the study.

\section{Recommendation}

Results that were achieved by the PRF need to be examined in different surgical techniques such as the envelope technique or the tunneling technique for a longer follow-up period. Further manipulation of biotype thickness by PRF can be a future point of research.

\section{References}

1. Gorman WJ. Prevalence and etiology of gingival recession. J Periodontol. 1967;38(4):316-22. PMid:5230025

2. Löst C. Depth of alveolar bone dehiscences in relation to gingival recessions. J Clin Periodontol. 1984;11(9):583-9. https://doi. org/10.1111/j.1600-051x.1984.tb00911.x PMid:6593330

3. American Academy of Periodontology. Glossary of Periodontal Terms. $3^{\text {rd }}$ ed. Chicago: The American Academy of Periodontology; 1992.

4. Serino G, Wennström JL, Lindhe J, Eneroth L. The prevalence and distribution of gingival recession in subjects with a high standard of oral hygiene. J Clin Periodontol. 1994;21(1):57-63. https://doi.org/10.1111/j.1600-051x.1994.tb00278.x

PMid:8126246

5. Daprile G, Gatto MR, Checchi L. The evolution of buccal gingival recessions in a student population: A 5-year follow-up. J Periodontol. 2007;78(4):611-4. https://doi. org/10.1902/jop.2007.060277

PMid:17397306

6. Miller AJ, Brunelle JA, Carlos JP, Brown LJ, Löe H. Oral Health of United States Adults. Bethesda, Maryland: NIH Publication, National Institute of Dental Research; 1987.

7. Chambrone L, Pannuti CM, Tu YK, Chambrone LA. Evidencebased periodontal plastic surgery. II. An individual data metaanalysis for evaluating factors in achieving complete root coverage. J Periodontol. 2012;83(4):477-90. https://doi. org/10.1902/jop.2011.110382

PMid:21859324

8. Reiser GM, Bruno JF, Mahan PE, Larkin LH. The subepithelial connective tissue graft palatal donor site: Anatomic considerations for surgeons. Int $\mathrm{J}$ Periodontics Restorative Dent. 1996;16(2):130-7.

PMid:9084301

9. Langer B, Langer L. Subepithelial connective tissue graft technique for root coverage. J Periodontol. 1985;56(12):715-20. https://doi.org/10.1902/jop.1985.56.12.715

PMid:3866056
10. Zucchelli G, Amore C, Sforza NM, Montebugnoli L, De Sanctis M. Bilaminar techniques for the treatment of recession-type defects. Acomparative clinical study. J Clin Periodontol. 2003;30(10):86270. https://doi.org/10.1034/j.1600-051x.2003.00397.x PMid:14710766

11. Harris RJ. A short-term and long-term comparison of root coverage with an acellular dermal matrix and a subepithelial graft. J Periodontol. 2004;75(5):734-43. https://doi.org/10.1902/ jop.2004.75.5.734

PMid: 15212356

12. Paolantonio M, Dolci M, Esposito P, D’Archivio D, Lisanti L, Di Luccio A, et al. Subpedicle acellular dermal matrix graft and autogenous connective tissue graft in the treatment of gingival recessions: A comparative 1-year clinical study. J Periodontol. 2002;73(11):1299-307 https://doi.org/10.1902 jop.2002.73.11.1299

PMid:12479634

13. Jankovic S, Aleksic Z, Klokkevold P, Lekovic V, Dimitrijevic B, Kenney EB, et al. Use of platelet-rich fibrin membrane following treatment of gingival recession: A randomized clinical trial. Int $J$ Periodontics Restorative Dent. 2012;32(2):e41-50. https://doi. org/10.11607/prd.0823

PMid:22292152

14. Padma R, Shilpa A, Kumar PA, Nagasri M, Kumar C, Sreedhar A. A split mouth randomized controlled study to evaluate the adjunctive effect of platelet-rich fibrin to coronally advanced flap in Miller's class-I and II recession defects. J Indian Soc Periodontol. 2013;17(5):631-6. https://doi. org/10.4103/0972-124x.119281

PMid:24174758

15. Eren G, Kantarcı A, Sculean A, Atilla G. Vascularization after treatment of gingival recession defects with platelet-rich fibrin or connective tissue graft. Clin Oral Investig. 2016;20(8):2045-53. https://doi.org/10.1007/s00784-015-1697-8 PMid:26696115

16. Matter J. Creeping attachment of free gingival grafts. A five-year follow-up study. J Periodontol. 1980;51(12):681-5. https://doi. org/10.1902/jop.1980.51.12.681 PMid:6937639

17. Dohan DM, Choukroun J, Diss A, Dohan SL, Dohan AJ, Mouhyi J et al. Platelet-rich fibrin (PRF): A second-generation platelet concentrate. Part I: Technological concepts and evolution. Oral Surg Oral Med Oral Pathol Oral Radiol Endod. 2006;101(3):e3744. https://doi.org/10.1016/j.tripleo.2005.07.008 PMid:16504849

18. Zumstein MA, Berger S, Schober M, Boileau P, Nyffeler RW, Horn $M$, et al. Leukocyte- and platelet-rich fibrin (L-PRF) for long-term delivery of growth factor in rotator cuff repair: Review, preliminary results and future directions. Curr Pharm Biotechnol. 2012;13(7):1196-206. https://doi. org/10.2174/138920112800624337

PMid:21740372

19. Lundberg $\mathrm{M}$, Wennström JL. Development of gingiva following surgical exposure of a facially positioned unerupted incisor. J Periodontol. 1988;59(10):652-5. https://doi. org/10.1902/jop.1988.59.10.652

PMid:3183916

20. Gülnihal E, Gül A. Platelet-rich fibrin in the treatment of bilatera gingival recessions. Clin Adv Periodontics. 2012;2(3):154-60.

21. Hiatt WH, Stallard RE, Butler ED, Badgett B. Repair following mucoperiosteal flap surgery with full gingival retention. J Periodontol. 1968;39(1):11-6. https://doi. org/10.1902/jop.1968.39.1.11 PMid:5244502

22. Tatakis DN, Chambrone L. The effect of suturing protocols 
on coronally advanced flap root-coverage outcomes: A metaanalysis. J Periodontol. 2016;87(2):148-55. https://doi. org/10.1902/jop.2015.150394

PMid:26447751

23. Grzesik WJ, Narayanan AS. Cementum and periodontal wound healing and regeneration. CritRev Oral Biol Med. 2002;13(6):47484. https://doi.org/10.1177/154411130201300605

PMid:12499241

24. Oliver RC, Löe H, Karring T. Microscopic evaluation of the healing and revascularization of free gingival grafts. J Periodontal Res. 1968;3(2):84-95. https://doi.org/10.1111/j.1600-0765.1968. tb01908.x

PMid:4249992

25. Nobuto T, Imai H, Yamaoka A. Microvascularization of the free gingival autograft. J Periodontol. 1988;59(10):639-46. https:// doi.org/10.1902/jop.1988.59.10.639

\section{PMid:3183914}

26. Dohan Ehrenfest DM, Bielecki T, Jimbo R, Barbé G, De Corso $\mathrm{M}$, Inchingolo $\mathrm{F}$, et al. Do the fibrin architecture and leukocyte content influence the growth factor release of platelet concentrates? An evidence-based answer comparing a pure platelet-rich plasma (P-PRP) gel and a leukocyte-and plateletrich fibrin (L-PRF). Curr Pharm Biotechnol. 2012;13(7):1145-52. https://doi.org/10.2174/138920112800624382

PMid:21740377

27. Dohan Ehrenfest DM, Andia I, Zumstein MA, Zhang CQ, Pinto NR, Bielecki T. Classification of platelet concentrates (platelet-rich plasma-PRP, platelet-rich fibrin-PRF) for topical and infiltrative use in orthopedic and sports medicine: Current consensus, clinical implications and perspectives. Muscles Ligaments Tendons J. 2014;4(1):3-9. https://doi.org/10.32098/ mltj.01.2014.02

PMid:24932440 